\title{
Internal Consistency and Concurrent Validity for the Critical Hire-Personality Assessment: A Replication Study with Correctional Officers
}

\author{
Tony Tatman
}

USA

Received: April 25, 2020 Accepted: June 1, 2020 Online published: June 15, 2020

doi:10.5296/ijhrs.v10i3.16907ＵRL: https://doi.org/10.5296/ijhrs.v10i3.16907

\begin{abstract}
The Critical Hire - Personality Assessment ( $\mathrm{CH}-\mathrm{PA})$ is a pre-employment personality assessment developed for law enforcement and correctional officer applicants. This study replicated findings provided by Tatman (2019) regarding the CH-PA's internal consistency and concurrent validity when compared to the NEO Personality Inventory-Revised. Results obtained in this study are consistent with findings obtained by Tatman (2019) and provide supporting evidence for the reliability and concurrent validity for the $\mathrm{CH}-\mathrm{PA}$ when used with a sample of correctional officer applicants.
\end{abstract}

Keywords: pre-employment testing, personality testing, correctional officers

\section{Introduction}

\subsection{Purpose and Literature Review}

Pre-employment personality testing for law enforcement applicants has become a rather common practice in the United States. Approximately $98 \%$ of agencies from communities of 25,000 or more citizens report using pre-employment personality tests to aid in their law enforcement hiring decisions (Reaves, 2010), while at least 38 states have codified, or otherwise require per policy, applicant personality tests (Corey \& Borum, 2013). This widespread use and popularity come, in part, from the rich empirical history showing personality testing's ability to adequately predict future workplace problems (Ones, Dilchert, Viswesvaran, \& Judge, 2007). One model of personality commonly used in pre-employment personality testing is the Five Factor Model (FFM; Digman, 1990; Goldberg, 1993). The FFM separates personality into five unique domains or factors: Neuroticism, Extraversion, Openness, Agreeableness and Conscientiousness (Wiggins, 1996). Research has revealed that the FFM has significant correlations with, and has high accuracy rates for predicting, various 
measures of work performance (Barrick, Mount, \& Judge, 2001; Furnham \& Fudge, 2008; Hurtz \& Donovan, 2000; Mount, Barrick, \& Stewart, 1998; Oh, Wang, \& Mount, 2011; Ones et al., 2007; Rothmann \& Coetzer, 2003; Salgado, 2002; Tett, Jackson, \& Rothstein, 1991). The FFM has also been used to measure the personality traits of law enforcement officers and applicants from various countries. For example, the FFM has been found to predict work-related stress reactions in law enforcement officers in Italy (Garbarino, Chiorri, \& Magnavita, 2014), burnout versus resilience in officers in South Africa (Louw, 2014), job performance ratings of officers in America (Detrick \& Chibnall, 2006), and academy performance in police cadets in New Zealand (Black, 2000) and America (Detrick, Chibnall, \& Luebbert, 2004).

Although many states identify correctional officers as peace officers (American Probation and Parole Association, 2006), the use of pre-employment personality testing has not been as widely used for correctional officer applicants as compared to police officer applicants. This limited use may stem, in part, from the lack of appropriate testing resources available to correctional hiring agencies. Tatman (2019) conducted an extensive search through the existing literature for pre-employment personality assessments for correctional officers. No tools were identified with published psychometrics or validation studies when used with correctional officers. As a result, Tatman developed the Critical Hire-Personality Assessment (CH-PA, Tatman, 2019), a FFM consistent personality assessment, to fill this gap in the pre-employment testing resources available for correctional hiring agencies. Tatman explored the psychometric properties of the CH-PA when used with correctional officers and found that it generated moderate to strong internal consistency coefficients, test re-test reliability, and criterion validity for predicting supervisor ratings of correctional officer job performance. The CH-PA scales and subscales also generated significant correlation coefficients with NEO Personality Inventory-R (NEO PI-R; Costa \& McCrae, 1992) factors and facets, respectively, that were identified as being conceptually similar, suggesting strong concurrent validity. Although initial reliability and concurrent validity research on the CH-PA, when used with correctional office applicants, has been promising, the existing research findings constitute data from only one study. For a test to show adequate reliability and validity multiple studies or sources are needed, representing a trend of findings as opposed to a single analysis (Tippins, Sackett, \& Oswald, 2018). Therefore, the purpose of this study is to replicate Tatman (2019) by examining the reliability and concurrent validity of the CH-PA with a sample of correctional officer applicants.

\section{Methods}

\subsection{Participants}

This sample consisted of 106 individuals (Males = 53; Females = 53) who applied for correctional officer positions within multiple rural and urban community-based corrections agencies in Iowa. The average age for participants in this sample was 34.43 ( $\mathrm{SD}=10.41$, Median =33), and ranged in age from 19 to 58. Racial/ethnic status for this sample consisted of 82 Caucasian, 15 African American, six Hispanic, two Bosnian, and one Asian participants. 


\subsection{Measures}

The CH-PA is a pre-employment personality assessment developed for law enforcement and correctional officer applicants. The CH-PA uses the Five Factor Model of personality (FFM; Digman, 1990) as its theoretical framework, and contains five personality scales and 17 subscales. The five CH-PA scales consist of Stress Response $(\alpha=.86)$, Extraversion $(\alpha=.85)$, Flexibility $(\alpha=.77)$, Agreeableness $(\alpha=.79)$, and Conscientiousness $(\alpha=.89)$ (Tatman, 2019). CH-PA questions are answered using a five-point, Likert-scale (e.g., Strongly Agree to Strongly Disagree).

In addition to the CH-PA, participants in this study also completed the NEO PI-R. The NEO PI-R was chosen in this study because, similar to the CH-PA, it uses the FFM as its theoretical framework, a model of personality identified as correlating with job performance and counterproductive behaviors (Barrick, Mount, \& Judge, 2001; Salgado, 2002). This consistency in theoretical foundations allows for optimal comparisons between two measures of personality. In addition to being theoretically comparable to the CH-PA, the NEO PI-R is also appropriate for this study based on empirical evidence supporting its reliability and validity when used in law enforcement officer personnel selection procedures (Barrick \& Mount, 1991; Detrick \& Chibnal, 2006; Detrick \& Chibnall, 2013; Detrick et. al., 2004). The NEO PI-R measures five factors of personality (Neuroticism, Extraversion, Openness, Agreeableness, and Conscientiousness). Each factor contains six facets or subscales. The NEO-PI-R has developed norms for men and women, as well as combined norms. Combined norms were used in this study.

\subsection{Research Design and Sampling Procedures}

This study utilized a secondary data analysis design. Agencies selected for inclusion into this study used the CH-PA and NEO PI-R as evaluation tools during their hiring process, providing naturally occurring, archival data. Participants in this sample completed the CH-PA and NEO PI-R as part of the agency's hiring process.

\section{Results}

\subsection{Statistical Analyses}

Concurrent validity was measured by calculating Pearson Correlation coefficients between CH-PA scales and NEO PI-R factors, as well as between CH-PA subscales and NEO PI-R facets. Internal consistency was measured by calculating Cronbach alphas.

\subsubsection{Statistics and Data Analysis}

CHP-PA scale and subscale Cronbach alpha scores, means, and standard deviations are provided in Table 1. Other than for CH-PA subscales Openness to Change $(\alpha=.56)$ and Modesty $(\alpha=.57)$, Cronbach alpha scores for the CH-PA scales and subscales showed adequate internal consistency. Results also revealed that NEO PI-R factors and their comparable CH-PA scales had significant correlation coefficients (Tables 2 to 6). Results also revealed significant relationships between NEO PI-R facets and their comparable CH-PA subscales (Tables 2 to 6 ). 
Table 1. CH-PA Scale and Subscale Alphas, Means, and Standard Deviations

\begin{tabular}{|c|c|c|c|}
\hline CH-PA & & & \\
\hline Subscales & Alpha & $M$ & $S D$ \\
\hline Stress Response & .84 & 29.91 & 6.17 \\
\hline Irritability & .79 & 8.69 & 2.31 \\
\hline Impulsivity & .65 & 11.57 & 2.88 \\
\hline Social Discomfort & .69 & 9.65 & 2.27 \\
\hline Extraversion & .86 & 66.74 & 7.64 \\
\hline Warmth & .80 & 21.09 & 2.31 \\
\hline Assertiveness & .79 & 15.15 & 2.28 \\
\hline Gregariousness & .72 & 12.64 & 2.65 \\
\hline Activity Level & .73 & 17.86 & 3.13 \\
\hline Flexibility & .75 & 29.47 & 4.17 \\
\hline Intellectual Curiosity & .81 & 14.76 & 3.01 \\
\hline Openness to Change & .56 & 14.71 & 1.97 \\
\hline Agreeableness & .83 & 70.49 & 6.71 \\
\hline Empathy & .77 & 28.92 & 3.00 \\
\hline Trust & .73 & 14.47 & 2.36 \\
\hline Modesty & .57 & 7.84 & 1.37 \\
\hline Conscientiousness & .89 & 81.64 & 8.08 \\
\hline Drive \& Self-Discipline & .81 & 38.28 & 3.37 \\
\hline Organization & .80 & 23.01 & 3.98 \\
\hline Dependability \& Reliability & .77 & 34.17 & 2.77 \\
\hline Deliberation & .78 & 26.50 & 4.22 \\
\hline
\end{tabular}

Table 2. NEO PI-R Neuroticism and CH-PA Stress Response Correlations

$\mathrm{CH}-\mathrm{PA}$

Scale Subscales

NEO PI-R $\quad$ Stress Response Irritability Impulsivity Social Discomfort

Factor

Neuroticism .54

Facets

Anxiety

Angry Hostility

Depression

Self-Consciousness

Impulsivity

Vulnerability

$\begin{array}{ccc}.29(.003) & .30(.002) & .44 \\ . \mathbf{6 9} & .50 & .40 \\ .33(.001) & .28(.004) & .46 \\ .37 & .39 & \mathbf{. 5 2} \\ .40 & .58 & .43 \\ .61 & .50 & .51\end{array}$

.44

.46

.52

43

Note: NEO PI-R facets and CH-PA subscales predetermined by Tatman (2019) as being conceptually similar are identified in bold. All correlation coefficients were significant at $p$ $<.0001$ unless otherwise noted.

Table 3. NEO PI-R Extraversion and CH-PA Extraversion Correlations 


\begin{tabular}{|c|c|c|c|c|c|}
\hline \multirow[b]{3}{*}{ NEO PI-R } & \multicolumn{5}{|c|}{ CH-PA } \\
\hline & \multirow{2}{*}{$\begin{array}{c}\text { Scale } \\
\text { Extraversion }\end{array}$} & \multicolumn{4}{|c|}{ Subscales } \\
\hline & & Warmth & Assertiveness & Gregariousness & Activity Level \\
\hline \multicolumn{6}{|l|}{ Factor } \\
\hline Extraversion & .56 & & & & \\
\hline \multicolumn{6}{|l|}{ Facets } \\
\hline Warmth & & .60 & $.33(.001)$ & .47 & $.27(.006)$ \\
\hline Gregariousness & & .47 & $.23(.017)$ & .72 & $.32(.001)$ \\
\hline Assertiveness & & .36 & .59 & .38 & $.26(.009)$ \\
\hline Activity & & $.33(.001)$ & .35 & $.25(.011)$ & .43 \\
\hline Excitement Seeking & & $.20(.041)$ & $.15(.139)$ & $.31(.001)$ & .41 \\
\hline Positive Emotions & & .55 & $.24(.014)$ & .50 & $.29(.003)$ \\
\hline
\end{tabular}

Note: NEO PI-R facets and CH-PA subscales predetermined by Tatman (2019) as being conceptually similar are identified in bold. All correlation coefficients were significant at $p$ $<.0001$ unless otherwise noted.

Table 4. NEO PI-R Openness to Experiences and CH-PA Flexibility Correlations

\begin{tabular}{llccc}
\hline & & \multicolumn{3}{c}{ CH-PA } \\
\cline { 3 - 5 } \multicolumn{2}{l}{ NEO PI-R } & \multicolumn{2}{c}{ Scale } & \multicolumn{2}{c}{ Subscales } \\
\cline { 3 - 5 } Factor & & Flexibility & Intellectual Curiosity & Openness to Change \\
\cline { 3 - 5 } Facets & & & \\
& & & & \\
& Fpenness & .56 & $.08(.41)$ & $-.15(.124)$ \\
& Fantasy & & $.33(.001)$ & $.25(.012)$ \\
& Aesthetics & & $.07(.476)$ & $-.02(.846)$ \\
& Feelings & & $.07(.457)$ &. $\mathbf{4 2}$ \\
& Actions & & .71 & $.24(.016)$ \\
& Ideas & & $.18(.064)$ & $.21(.038)$ \\
& Values & & &
\end{tabular}

Note: NEO PI-R facets and CH-PA subscales predetermined by Tatman (2019) as being conceptually similar are identified in bold. All correlation coefficients were significant at $p$ $<.0001$ unless otherwise noted.

Table 5. NEO PI-R Agreeableness and CH-PA Agreeableness Correlations 


\begin{tabular}{|c|c|c|c|c|}
\hline \multirow[b]{3}{*}{ NEO PI-R } & \multicolumn{4}{|c|}{ CH-PA } \\
\hline & \multirow{2}{*}{$\begin{array}{c}\text { Scale } \\
\text { Agreeableness }\end{array}$} & \multicolumn{3}{|c|}{ Subscales } \\
\hline & & Empathy & Trust & Modesty \\
\hline \multicolumn{5}{|l|}{ Factor } \\
\hline Agreeableness & .60 & & & \\
\hline \multicolumn{5}{|l|}{ Facets } \\
\hline Trust & & .43 & .59 & $.18(.071)$ \\
\hline Straightforwardness & & .41 & .40 & $.25(.011)$ \\
\hline Altruism & & .41 & .34 & $.04(.674)$ \\
\hline Compliance & & .38 & $.23(.018)$ & $.14(.169)$ \\
\hline Modesty & & $.25(.012)$ & $.13(.208)$ & $.33(.001)$ \\
\hline Tender Mindedness & & .49 & $.22(.027)$ & $.05(.593)$ \\
\hline
\end{tabular}

Note: NEO PI-R facets and CH-PA subscales predetermined by Tatman (2019) as being conceptually similar are identified in bold. All correlation coefficients were significant at $p$ $<.0001$ unless otherwise noted.

Table 6. NEO PI-R Conscientiousness and CH-PA Conscientiousness Correlations

\begin{tabular}{|c|c|c|c|c|c|}
\hline \multirow[b]{3}{*}{ NEO PI-R } & \multicolumn{5}{|c|}{ CH-PA } \\
\hline & \multirow{2}{*}{$\begin{array}{c}\text { Scale } \\
\text { Conscientiousness }\end{array}$} & \multicolumn{4}{|c|}{ Subscales } \\
\hline & & $\begin{array}{c}\text { Drive \& } \\
\text { Self-Discipline }\end{array}$ & $\begin{array}{l}\text { Dependability } \\
\text { \& Reliability }\end{array}$ & Organization & Deliberation \\
\hline \multicolumn{6}{|l|}{ Factor } \\
\hline Conscientiousness & .72 & & & & \\
\hline \multicolumn{6}{|l|}{ Facets } \\
\hline Competence & & .63 & .66 & .46 & .51 \\
\hline Order & & .56 & .40 & .69 & .62 \\
\hline Dutifulness & & .56 & .56 & .53 & .54 \\
\hline Achievement Striving & & .53 & .48 & $.33(.001)$ & $.28(.004)$ \\
\hline Self-Disciplined & & .71 & .68 & .58 & .53 \\
\hline Deliberation & & .57 & .53 & .59 & .67 \\
\hline
\end{tabular}

Note: NEO PI-R facets and CH-PA subscales predetermined by Tatman (2019) as being conceptually similar are identified in bold. All correlation coefficients were significant at $p$ $<.0001$ unless otherwise noted.

\section{Discussion}

Other than for the CH-PA Openness to Change and Modesty subscales, alpha coefficients obtained in this study for the CH-PA scales and subscales showed adequate internal consistency. Alphas obtained for Openness to Change and Modesty differ from Tatman (2019) who found internal consistency coefficients of .62 and .64, respectively. However, it should be noted that these two subscales were the only subscales reported by Tatman with alphas falling below .70, suggesting that the present study may have highlighted low internal consistency for Openness to Change and Modesty that was originally identified by Tatman. Therefore, the present findings combined with those found by Tatman would suggest that the 
internal consistency of the Openness to Change and Modesty subscales appear to have questionable internal consistency. The remaining $\mathrm{CH}-\mathrm{PA}$ scales and subscale alphas are consistent with those found by Tatman, and establish a growing pattern of empirical support for the tool's internal consistency. Correlation coefficients obtained in this study were also consistent with Tatman (2019), which suggest that the CH-PA is measuring similar constructs as the NEO PI-R and provides supporting evidence that the $\mathrm{CH}-\mathrm{PA}$ has adequate concurrent validity as a measure of normal personality traits. These findings are important to the field of pre-employment personality testing by providing empirical evidence for the CH-PA's reliability and validity when used with correctional officer applicants. These findings are also important to the field as it initiates a pattern of findings required by the Uniform Guidelines on Employee Selection Procedures (UGESP; Uniform Guidelines on Employee Selection Procedure, 1978). The UGESP was adopted by the Equal Employment Opportunity Commission and delineates guidelines for determining the proper use of tests and other applicant selection procedures. UGESP guidelines require that selection instruments, such as pre-employment personality testing, show evidence for the validity, reliability, and applicability for the particular job it is being used with (i.e., correctional officer applicants). Findings obtained in this study help provide the empirical evidence required by the UGESP.

\section{References}

American Probation and Parole Association (2006). Peace officer status of probation and parole officers. Retrieved from https://www.appa-net.org/eweb/Resources/Surveys/National_Firearms/docs/Peace_Officer_St atus_2006_10.pdf

Barrick, M. R., \& Mount, M. K. \& Judge, T. A. (2001). The FFM personality dimensions and job performance: Meta-analysis of meta-analyses. International Journal of Selection and Assessment, 9, 9-30. https://doi.org/10.1111/1468-2389.00160

Barrick, M. R., \& Mount, M. K. (1991). The Big Five personality dimensions and job performance: A meta-analysis. Personnel Psychology, 44(1), 1-26. https://doi.org/10.1111/j.1744-6570.1991.tb00688.x

Black, J. (2000). Personality testing and police selection: Utility of the "Big Five." New Zealand Journal of Psychology, 29, 2-9.

Corey, D. M., \& Borum, R. (2013). Forensic assessment for high-risk occupations. In R. K. Otto \& I. B. Weiner (Eds.), Forensic psychology (pp. 246-270). Hoboken, NJ: John Wiley \& Sons, Inc. https://doi.org/10.1002/9781118133880.hop211011

Costa, P. T., Jr., \& McCrae, R. R. (1992) NEO PI-R professional manual. Odessa, FL: Psychological Assessment Resources.

Detrick, P., \& Chibnall, J. T. (2006). NEO PI-R personality characteristics of high-performing entry-level police officers. Psychological Services, 3(4), 274-285. https://doi.org/10.1037/1541-1559.3.4.274

Detrick, P., \& Chibnall, J. T. (2013). Revised NEO Personality Inventory normative data for 
$\begin{array}{lllll}\text { police officer } & \text { selection. } & \text { Psychological } & \text { Services, } & 10(4),\end{array}$ https://doi.org/10.1037/a0031800

Detrick, P., Chibnall, J. T., \& Luebbert, M. C. (2004). The Revised NEO Personality Inventory as predictor of police academy performance. Criminal Justice and Behavior, 31(6), 676-694. https://doi.org/10.1177/0093854804268751

Digman, J. M. (1990). Personality structure: Emergence of the five-factor model. Annual Review of Psychology, 41, 417-440. https://doi.org/10.1146/annurev.ps.41.020190.002221

Furnham, A., \& Fudge, C. (2008). The Five Factor Model of Personality and sales performance. Journal of Individual Differences, 29, 11-16. https://doi.org/10.1027/1614-0001.29.1.11

Garbarino, S., Chiorri, C., \& Magnavita, N. (2014). Personality traits of the Five-Factor Model are associated with work-related stress in special force police officers. International Archives of Occupational and Environmental Health, 87(3), 295-306. https://doi.org/10.1007/s00420-013-0861-1

Goldberg, L. R. (1993). The structure of phenotypic personality traits. American Psychologist, 48, 26-34. https://doi.org/10.1037/0003-066X.48.1.26

Hurtz, G. M., \& Donovan, J. J. (2000). Personality and job performance: The Big Five $\begin{array}{llll}\text { revisited. Journal of Applied Psychology, } & 85(6), & 869-879 .\end{array}$ https://doi.org/10.1037/0021-9010.85.6.869

Louw, G. J. (2014). Burnout, vigour, big five personality traits and social support in a sample of police officers. SA Journal of Industrial Psychology, 40(1). https://doi.org/10.4102/sajip.v40i1.1119

Mount, M. K., Barrick, M. R., \& Stewart, G. L. (1998). Five-factor model of personality and performance in jobs involving interpersonal interactions. Human Performance, 11(2-3), 145-165. https://doi.org/10.1207/s15327043hup1102\&3_3

Oh, I.-S., Wang, G., \& Mount, M. K. (2011). Validity of observer ratings of the Five Factor Model of Personality traits: A meta-analysis. Journal of Applied Psychology, 96(4), 762-773. https://doi.org/10.1037/a0021832

Ones, D. S., Dilchert, S., Viswesvaran, C., \& Judge, T. A. (2007). In support of personality assessment in organizational settings. Personnel Psychology, 60(4), 995-1027. https://doi.org/10.1111/j.1744-6570.2007.00099.x

Reaves, B. A. (2010). Local police departments, 2007. (NCJ Publication No. 231174). Retrieved from US Department of Justice, Office of Justice Programs, Bureau of Justice Statistics website: https://www.bjs.gov/content/pub/pdf/lpd07.pdf

Rothmann, S., \& Coetzer, E. P. (2003). The big five personality dimensions and job $\begin{array}{lllll}\text { performance. SA Journal of Industrial Psychology, } & \text { 29(1). }\end{array}$ https://doi.org/10.4102/sajip.v29i1.88 


\section{Macrothink}

International Journal of Human Resource Studies

ISSN 2162-3058 2020, Vol. 10, No. 3

Salgado, J. F. (2002). The Big Five personality dimensions and counterproductive behaviors. International Journal of Selection and Assessment, 10(1/2), 117-125. https://doi.org/10.1111/1468-2389.00198

Tatman, A. W. (2019). Initial Reliability and Validity of the Critical Hire-Personality Assessment. Corrections: Policy, Practice and Research. https://doi.org/10.1080/23774657.2019.1699477

Tett, R. P., Jackson, D. N., \& Rothstein, M. (1991). Personality measures as predictors of job performance: A meta-analytical review. Personnel Psychology, 44(4), 703-742. https://doi.org/10.1111/j.1744-6570.1991.tb00696.x

Tippins, N., Sackett, P., \& Oswald, F. L. (2018). Principles for the Validation and Use of Personnel Selection Procedures. Industrial and Organizational Psychology, 11(S1), 1-97. https://doi.org/10.1017/iop.2018.195

Uniform Guidelines on Employee Selection Procedure (1978); 43 FR 38295 (August 25, 1978). Retrieved from http://uniformguidelines.com/uniformguidelines.html\#20

Wiggins, J. S. (1996). The five-factor model of personality: Theoretical Perspectives. New York, NY: The Guilford Press.

\section{Copyright Disclaimer}

Copyright for this article is retained by the author(s), with first publication rights granted to the journal.

This is an open-access article distributed under the terms and conditions of the Creative Commons Attribution license (http://creativecommons.org/licenses/by/4.0/). 